\title{
Analisis Miskonsepsi Siswa dalam Menyelesaikan Soal Pecahan Berdasarkan Kerangka Kerja Asimilasi dan Akomodasi di MTsN 4 Kerinci
}

\author{
Eltati Tri Aldianisa ${ }^{1}$, Nizlel Huda ${ }^{2}$, Muhammad Haris Effendi-Hsb ${ }^{3}$ \\ 1, 2,3 Program Studi Magister Pendidikan Matematika, Fakultas Pascasrjana, Universitas jambi, \\ Jl. Jambi-Muaro Bulian KM.15 Mandalo Indah Muaro Jambi, Jambi, Indonesia \\ ealdianisa@gmail.com
}

\begin{abstract}
Misconceptions often occur in students who have incomplete or imperfect initial concepts, making it difficult for students to assimilate new information into their existing conceptual structures. Aims to find out the process of students' misconceptions in solving fraction problems based on the assimilation and accommodation framework. This research is a qualitative descriptive research, this research is based on a case study. Case studies focus on programs, events, or activities that involve individuals rather than groups. This research was conducted at MTsN 4 in February 2021-March 2021, the subjects in this study were students of MTsN 4 Kerinci. The technique of taking the subject is using purposive sampling. The research instrument is the researcher himself because the researcher has a special position, namely as a planner, implementer of data collection, analysis, interpretation of data, and pioneer of research results. Other instruments are fractional material tests and unstructured interviews. Data analysis techniques include data reduction (data reduction), data presentation (data display) as well as drawing conclusions and verification (conclusion drawing/verification). The conclusion in this study is that students' misconceptions occur in solving fractional material problems based on the assimilation and accommodation framework.
\end{abstract}

Keywords: Misconception, Solving, Assimilation and Accommodation

\begin{abstract}
Abstrak
Miskonsepsi sering terjadi pada siswa yang memiliki konsep awal yang kurang lengkap atau tidak sempurna menyulitkan siswa dalam mengasimilasi informasi baru ke dalam struktur konseptual mereka yang sudah ada. Bertujuan untuk mengetahui proses terjadinya miskonsepsi pada siswa dalam menyelesaikan soal pecahan berdasarkan kerangka kerja asimilasi dan akomodasi. Penelitian ini merupakan penelitian deskriptif kualitatif, penelitian ini berlandaskan studi kasus. Studi kasus berfokus pada program, acara, atau kegiatan yang melibatkan individu dari pada kelompok. Penelitian ini dilaksanakan di MTsN 4 pada Februari 2021-Maret 2021, subjek dalam penelitian ini siswa MTsN 4 Kerinci. Teknik pengambilan subjek menggunakan purposive sampling. Instrumen penelitian adalah peneliti itu sendiri, karena peneliti memiliki kedudukan yang khusus, yaitu sebagai perencana, pelaksana pengumpulan data, analisis, penafsiran data, serta pelopor hasil penelitian. Instrumen lainnya tes materi pecahan dan wawancara tidak terstruktur. Teknik analisis data meliputi reduksi data (data reduction), penyajian data (data display) serta penarikan kesimpulan dan verifikasi (conclusion drawing/ verification). Kesimpulan dalam penelitian ini terjadi miskonsepsi siswa dalam menyelesaikan soal materi pecahan berdasarkan kerangka kerja asimilasi dan akomodasi.
\end{abstract}

Kata kunci: Miskonsepsi, Pemecahan, Asimilasi dan Akomodasi

Copyright (c) 2021 Eltati Tri Aldianisa, Nizlel Huda, Muhammad Haris Effendi-Hsb

$\triangle$ Corresponding author: Nizlel Huda

Email Address: nizlel@yahoo.com (Jl. Jambi-Muaro Bulian KM.15 Mandalo Indah Muaro Jambi, Jambi, Indonesia) Received 22 June 2021, Accepted 05 July 2021, Published 02 August 2021

\section{PENDAHULUAN}

Pemahaman konsep pembelajaran yang lebih baik dalam matematika, penting untuk mengetahui pengetahuan siswa sebelumnya dan mengembangkan strategi baru yang sesuai dengan pengetahuan saat ini (Akdeniz et al., 2000). Demikian pula, (Ausubel et al., 1968) menganjurkan bahwa pengetahuan konseptual siswa yang ada pada bidang tertentu dapat membuat dampak paling signifikan pada pembelajaran konseptual siswa. Karena belajar tergantung pada tingkat kognitif peserta didik dan kompleksitas konsep yang harus dipelajari, tidak mungkin untuk berharap bahwa setiap individu akan mempelajari konsep dengan kecepatan yang sama atau dengan cara yang benar (Fidan, 1986). Dengan demikian, dalam proses 
pembelajaran konsep matematika ini, beberapa siswa dapat keluar dari jalan dan menghasilkan kesalahfahaman yang disebut sebagai miskonsepsi (Meşeci et al., 2013).

Miskonsepsi diartikan sebagai pemahaman konsep yang tidak sesuai dengan pengertian ilmiah atau kesepakatan para ahli pada bidang tersebut (Suparno, 2013). Sementara itu, (Thompson \& Logue, 2006) mendefinisikan miskonsepsi sebagai kesalahan seseorang dalam memahami ide atau konsep yang dibangun berdasar pengalamannya. Miskonsepsi matematika dapat juga berupa kesalahan dalam aplikasi sebuah aturan atau generalisasi yang kurang tepat. Ketika seseorang secara sistematis menggunakan aturan yang salah atau mengunakan aturan yang benar, tetapi digunakan di luar aplikasinya. Hal tersebut juga disebut miskonsepsi.

Miskonsepsi siswa sering terjadi pada salah satu materi matematika yakni pecahan. Pecahan merupakan salah satu materi penting dalam pembelajaran matematika yang termasuk ke dalam aspek bilangan. Pecahan merupakan konsep dasar dan merupakan materi prasyarat untuk mempelajari dan memahami jenis bilangan yang lainnya seperti bilangan riil dan bilangan kompleks. Konsep pecahan merupakan konsep yang berbeda dengan konsep bilangan bulat karena pecahan merupakan bilangan diantara dua bilangan bulat, hal ini menjadi salah satu penyebab sulitnya mengajarkan pecahan baik di tingkat sekolah dasar, maupun sekolah menengah (Kemendikbud, 2012).

Untuk memahami konsep pecahan siswa, siswa perlu memiliki pemahaman yang jelas tentang sifat pecahan. Siswa umumnya membangun pengetahuan tentang pecahan dari pengetahuan yang ada. Jika pengetahuan yang ada terkontaminasi dengan miskonsepsi konseptual, akan mempengaruhi pembelajaran siswa dimasa depan terkait konsep tersebut (Alghazo \& Alghazo, 2017). Siswa yang membawa atau memiliki konsep awal yang kurang lengkap atau tidak sempurna ini dapat mengalami kesalahan konsep atau miskonsepsi.

Miskonsepsi yang terjadi saat siswa yang membawa atau memiliki konsep awal yang kurang lengkap atau tidak sempurna menyulitkan siswa dalam mengasimilasi informasi baru ke dalam struktur konseptual mereka yang sudah ada. Konsep awal yang tidak lengkap atau tidak sempurna tersebut juga akan menyulitkan siswa untuk memahami konsep selanjutnya. Perilaku siswa tersebut terkait dengan proses asimilasi dan akomodasi. Dalam proses asimilasi, ia menyerap rangsangan baru secara langsung dan mengintegrasikannya ke dalam skema pengetahuan yang ada. Ketika mengasimilasi informasi baru ke dalam struktur konseptual mereka yang sudah ada. Siswa meskipun telah berkali-kali menerima konsep yang sama, namun masih memerlukan suatu proses untuk dapat menyelesaikan masalah yang ada sesuai dengan konsep yang sebenarnya. Struktur pengetahuan yang ada tidak dapat secara langsung menyerap rangsangan baru karena perlu fase untuk memodifikasi struktur untuk mengatasi rangsangan baru dan kemudian akan diintegrasikan. Dari penjelesan diatas dapat disimpulkan bahwa menurut psikologi kognitif, timbulnya miskonsepsi disebabkan adanya asimilasi dan akomodasi pada otak manusia dalam menanggapi dan memahami informasi yang baru diterimanya (Maulana, 2010).

Miskonsepsi dalam menyelesaikan soal matematika terutama pada materi pecahan dapat menjadi masalah serius jika tidak segera diperbaiki. Sebab kesalahan satu konsep dasar matematika saja dapat 
menuntun seorang siswa pada kesalahan yang terus menerus. Miskonsepsi yang terjadi pada siswa harus dihilangkan dan harus menjadi perhatian khusus bagi guru serta siswa itu sendiri, Miskonsepsi pada konsep pecahan dapat berakibat kesalahan konsep pada konsepsi matematika berikutnya. Apabila tidak segera diatasi, siswa akan tetap mempertahankan konsep yang salah. Sebagai akibatnya, guru mengalami kesulitan dalam melaksanakan proses pembelajaran untuk mengubah atau mengkoreksi konsep yang salah tersebut. Sehingga proses pembelajaran akan terganggu, yang akan mengakibatkan menurunnya prestasi siswa dalam pembelajaran matematika.

Berdasarkan hasil observasi awal yang dilakukan penulis di MTsN 4 Kerinci, ditemukan siswa yang melakukan miskonsepsi ketika menyelesaikan soal matematika materi pecahan. Siswa tidak dapat menjawab soal dengan benar karena siswa belum memahami dengan baik faham konsep dasar matematika untuk materi pecahan.

Miskonsepsi ini terjadi akibat dari ketidakpahaman siswa terhadap konsep matematika terutama konsep pecahan yang berakibat pada kesalahan dalam menyelesaikan soal. Jawaban siswa menunjukkan bahwa ada konsep yang telah dikuasai namun tidak sesuai dengan konsep baru yang diterima. Meskipun siswa telah mampu menjelaskan apa yang mereka diketahui dan apa yang ditanyakan dari soal, namun siswa masih tidak dapat menjawab dengan benar soal yang diberikan.

Miskonsepi siswa ketika dihadapkan dengan beberapa jenis operasi hitung yang berbeda disebabkan oleh intuisi yang salah, siswa menganggap semua operasi hitung sama derajatnya. Meskipun materi tentang bilangan dan operasi hitung sudah seringkali mereka terima dan pelajari sebelumnya, namun intuisi yang muncul di benak siswa adalah pengertian yang spontan, bahwa semua operasi hitung adalah sama derajatnya.

Untuk melihat lebih lanjut bagaimana miskonsepsi siswa yang terjadi, perlu adanya analisis yang bertujuan menganalisis miskonsepsi yang dialami siswa dan hal-hal yang menjadi penyebab miskonsepsi siswa dalam menyelesaikan soal materi pecahan. Oleh sebab itu, peneliti tertarik untuk melakukan penelitian dengan judul "Analisis Miskonsepsi Siswa Dalam Menyelesaikan Soal Pecahan Berdasarkan Kerangka Kerja Asimilasi dan Akomodasi di MTs N 4 Kerinci”.

\section{METODE}

Penelitian ini merupakan penelitian deskriptif kualitatif, yang bermaksud untuk memahami fenomena tentang apa yang dialami oleh subjek penelitian, misalnya perilaku, persepsi, motivasi, tindakan, dan lain-lain, secara holistik (utuh) dengan cara mendeskripsikannya dalam bentuk kata-kata dan bahasa, pada suatu konteks khusus yang alamiah dan dengan memanfaatkan berbagai metode alamiah yang dimaksudkan untuk mengumpulkan informasi mengenai status suatu variable atau tema, gejala, atau keadaan yang ada, yaitu keadaan gejala menurut apa adanya pada saat penelitian dilakukan (Moleong, 2013). Penelitian ini berlandaskan studi kasus. Menurut (Creswell, 2002) penelitian studi kasus berfokus pada program, acara, atau kegiatan yang melibatkan individu dari pada kelompok. 
Subjek dalam penelitian ini yaitu siswa MTsN 4 Kerinci.Subjek penelitian ini dipilih dengan menggunakan purposive sampling.Subjek diberikan soal tes, jika subjek memenuhi kriteria yang dibutuhkan makan akan di analisis, jika subjek tidak memenuhi kriteria maka tidak akan di analisis (Creswell, 2002). Penelitian ini dilaksanakan di MTsN 4 Kerinci. Penelitian ini dilakukan pada Februari 2021-Maret 2021.

Instrument penelitian adalah peneliti itu sendiri, karena peneliti memiliki kedudukan yang khusus, yaitu sebagai perencana, pelaksana pengumpulan data, analisis, penafsiran data, serta pelopor hasil penelitian (Moleong, 2013). Instrumen lainnya adalah tes materi pecahan dan wawancara tidak terstruktur untuk mengungkap proses terjadinya miskonsepsi siswa berdasarkan kerangka kerja asimilasi dan akomodasi.

Teknik pengumpulan data dilakukan dengan meminta pertimbangan kepada para ahli mengenai kelayakan soal tes yang akan digunakan dalam penelitian. Selanjutnya peneliti memilih subjek dengan pertimbangan tertentu. Setelah subjek terpilih, peneliti meminta subjek untuk menyelesaikan soal materi pecahan. Dalam proses menyelesaikan masalah subjek mengungkapkan secara lengkap apa yang sedang dipikirkannya melalui kata-kata. Peneliti merekam ungkapan verbal maupun prilaku (ekspresi) subjek menggunakan bantuan handphone pengumpulan data semacam ini tergolong dalam metode think out load. Setelah subjek selesai dalam mengerjakan soal materi pecahan, peneliti melakukan wawancara tidak terstruktur kepada subjek tentang kata-kata yang diungkapkan oleh subjek dan ekspresi subjek pada saat mengerjakan tes miskonsepsi siswa berdasarkan kerangka kerja asimilasi dan akomodasi.

Dalam melakukan wawancara peneliti mempersiapkan alat bantu wawancara berupa alat tulis, alat perekam suara (recorder), camera dan lembar jawaban subjek dari soal tes pemecahan masalah tersebut. Alat tulis digunakan untuk mencatat informasi-informasi seperti biodata subjek penelitian. Sedangkan recorder digunakan untuk merekam komunikasi lisan antara peneliti dan responden. Lembar jawaban digunakan untuk mengarahkan penulis dalam menelusuri proses pemecahan masalah subjek penelitian.

Teknik analisis data yang digunakan pada penelitian ini meliputi reduksi data (data reduction), penyajian data (data display) serta penarikan kesimpulan dan verifikasi (conclusion drawing/ verification). Reduksi data merupakan suatu bentuk analisis yang menajamkan, menggolongkan, mengarahkan, membuang yang tidak perlu, dan mengorganisasi data dengan cara sedemikian rupa hingga kesimpulankesimpulan finalnya dapat ditarik dan diverifikasi. Penyajian data merupakan sekumpulan informasi tersusun yang memberi kemungkinan adanya penarikan kesimpulan dan pengambilan tindakan. Penarikan kesimpulan hanyalah sebagian dari satu kegiatan dari konfigurasi yang utuh. Kesimpulan-kesimpulan juga diverifikasi selama penelitian berlangsung.

\section{HASIL DAN DISKUSI}

\section{Hasil Penelitian Proses Terjadinya Miskonsepsi Siswa Dalam Menyelesaiakan Soal Materi Pecahan}

Dalam penelitian ini, dilakukan penelitian kepada 12 orang siswa namun yang bisa menjadi subjek penelitian hanya 3 orang siswa yang terdiri dari subjek 1 (S1), subjek 2 (S2), subjek 3 (S3), dikarenakan 9 
orang siswa tidak sesuai dengan kriteria subjek yang diinginkan. Penelitian ini dilakukan dalam 12 kali pertemuan. Pertemuan pertama dilakukan kepada 1 orang siswa, pertemuan selanjutnya dilakukan kepada 1 orang siswa di setiap pertemuan. Dalam penelitian ini yang data yang dipaparkan satu subjek.

\section{Paparan Data Subjek Pertama (S1)}

Tabel 1. Miskonsepsi S1 dalam Menyelesaikan Soal Materi Pecahan Berdasarkan Kerangka Kerja Asimilasi dan Akomodasi

\begin{tabular}{|c|c|c|c|c|c|c|}
\hline $\begin{array}{c}\text { Jenis } \\
\text { Miskonsepsi }\end{array}$ & $\begin{array}{c}\text { Indikator } \\
\text { Miskonsepsi }\end{array}$ & \multicolumn{2}{|r|}{ Perilaku Subjek } & $\begin{array}{c}\text { Kriteria } \\
\text { Jawaban } \\
\text { Subjek } \\
\end{array}$ & \multirow{2}{*}{$\begin{array}{c}\begin{array}{c}\text { Kategori } \\
\text { Pemahaman } \\
\text { Konsep }\end{array} \\
\text { Miskonsepsi }\end{array}$} & \multirow{2}{*}{$\begin{array}{c}\text { Kode } \\
\begin{array}{c}\text { M1AK } \\
4\end{array}\end{array}$} \\
\hline $\begin{array}{l}\text { Miskonsepsi } \\
\text { Klasifikasional }\end{array}$ & $\begin{array}{l}\text { Siswa } \\
\text { melakukan } \\
\text { kesalahan } \\
\text { dalam } \\
\text { mengurutkan } \\
\text { pecahan }\end{array}$ & Akomodasi & $\begin{array}{l}\text { 1. S1 mengatakakan bahwa } \frac{7}{20} \\
\text { nilainya lebih besar dari } \frac{7}{6}, \frac{7}{6} \text { lebih } \\
\text { besar dari } \frac{3}{4} \text { dan } \frac{3}{4} \text { lebih besar dari } \frac{1}{2} \\
\text { dikarenakan memiliki nilai } \\
\text { penyebut yang lebih besar. } \\
\text { 2. S1 mengatakan bahwa semakin } \\
\text { besar penyebut suatu pecahan, maka } \\
\text { semakin besar nilai pecahannya } \\
\text { 3. S1 menuliskan } \frac{1}{2}, 75 \%, 1 \frac{1}{6}, 0,35 \\
\text { sebagai urutan pecahan dari yang } \\
\text { terkecil hingga ke terbesar. }\end{array}$ & $\begin{array}{lr}\text { Ada } & \text { konsep } \\
\text { yang dikuasai } \\
\text { tapi dalam } \\
\text { jawaban masih } \\
\text { terdapat } \\
\text { pernyataan yang } \\
\text { menunjukkan } \\
\text { miskonsepsi }\end{array}$ & & \\
\hline \multirow[t]{2}{*}{$\begin{array}{l}\text { MiskonsepsiTeo } \\
\text { ritikal }\end{array}$} & \multirow[t]{2}{*}{$\begin{array}{l}\text { Siswamenga } \\
\text { nggapoperasi } \\
\text { hitungpadape } \\
\text { cahansamade } \\
\text { nganoperasih } \\
\text { itungpadabila } \\
\text { nganbulat. }\end{array}$} & Asimilasi & $\begin{array}{l}\text { Soal } 2 . b \\
\text { 1. S1 mengalikan } \frac{5}{6} \text { dan } \frac{3}{5} \text { dengan } \\
\text { menggunakan formula } \frac{a}{b} \times \frac{c}{d}= \\
\frac{a c}{b d}\left(\frac{5}{6} \times \frac{3}{5}=\frac{15}{30}\right) \\
\text { 2. S1 mengubah } 1 \frac{1}{2} \text { menjadi } \frac{3}{2} \\
\text { 3. S1 membagikan } \frac{18}{34} \text { dan } \frac{3}{2} \text { dengan cara } \\
\text { mengganti pembagian menjadi } \\
\text { perkalian dan membalikkan } \\
\text { pembaginya }\left(\frac{3}{2} \text { dibalik menjadi } \frac{2}{3}\right) \\
\text { Ketika mengalikan } \frac{18}{34} \text { dan } \frac{2}{3} \text { dengan } \\
\text { menggunakan formula } \frac{a}{b} \times \frac{c}{d}=\frac{a c}{b d}, \\
\text { S1 melakukan kesalahan dalam } \\
\text { perhitugan }\left(\frac{18}{34} \times \frac{2}{3}=\frac{36}{108}\right) \\
\text { S1 menyederhanakan } \frac{36}{108} \text { dengan } \\
\text { menggunakan formula } \frac{a}{b}=\frac{k a}{k b} \text { dan } \\
\text { diperoleh } \frac{36}{108}=\frac{4}{12}=\frac{2}{6}=\frac{1}{3}\end{array}$ & $\begin{array}{l}\text { Ada konsep } \\
\text { yang dikuasai } \\
\text { tapi dalam } \\
\text { menjawab } \\
\text { masih } \\
\text { menunjukkan } \\
\text { miskonsepsi }\end{array}$ & $\begin{array}{c}\text { Memahami } \\
\text { dan } \\
\text { Miskonsepsi } \\
\text { (Miskonsepsi) }\end{array}$ & $\begin{array}{c}\text { M2AS } \\
4\end{array}$ \\
\hline & & Akomodasi & $\begin{array}{l}\text { Soal 2.a } \\
\text { S1 menjumlahkan } \frac{21}{12} \text { dan } \frac{1}{2} \text { dengan } \\
\text { cara menjumlahkan pembilang- } \\
\text { pembilangnya dan menjumlahkan } \\
\text { penyebut-penyebutnya sehingga } \\
\text { diperoleh }\left(\frac{21}{12}+\frac{1}{2}=\frac{21+1}{12+2}=\frac{22}{14}\right) \\
\backslash \\
\text { Soal } 2 . b \\
\text { 1. S1 menjumlahkan } \frac{15}{30} \text { dan } \frac{3}{5} \text { dengan } \\
\text { cara menjumlahkan pembilang- } \\
\text { pembilangnya dan menjumlahkan } \\
\text { penyebut-penyebutnya } \\
\text { Ketika menjumlahkan penyebut- } \\
\text { penyebutnya, S1 melakukan } \\
\text { kesalahan dalam perhitungan }\left(\frac{15}{30}+\right. \\
\left.\frac{3}{5}=\frac{18}{34}\right)\end{array}$ & $\begin{array}{l}\text { Ada konsep } \\
\text { yang dikuasai } \\
\text { tapi dalam } \\
\text { menjawab } \\
\text { masih } \\
\text { menunjukkan } \\
\text { miskonsepsi }\end{array}$ & $\begin{array}{l}\text { Memahami } \\
\text { dan } \\
\text { Miskonsepsi } \\
\text { (Miskonsepsi) } \\
\\
\\
\text { Memahami } \\
\text { dan } \\
\text { Miskonsepsi } \\
\text { (Miskonsepsi) }\end{array}$ & $\begin{array}{l}\text { M2AK } \\
4\end{array}$ \\
\hline
\end{tabular}


Berdasarkan hasil paparan data dan analisis yang telah di uraikan, menunjukkan bahwa terjadi miskonsepsi ketika siswa menyelesaikan soal materi pecahan. berikut pembahasan proses terjadinya miskonsepsi berdasarkan kerangka kerja asimilasi dan akomodasi.

\section{Miskonsepsi Klasifikasional}

Menurut (Amien, 1990) miskonsepsi klasifikasional adalah bentuk miskonsepsi yang didasarkan atas kesalahan klasifikasi fakta-fakta ke dalam bagan- bagan yang terorganisir. Indikator miskonsepsi klasifikasional ini adalah siswa menunjukkan kesalahan dalam mengurutkan pecahan dari yang terkecil hingga ke yang terbesar.

\section{Miskonsepsi Klasifikasional S1}

Ketika menjawab soal pertama, S1 telah mampu membedakan beberapa bilangan pecahan. S1 mampu menunjukkan keempat pecahan berbeda yang terdapat pada soal pertama. S1 yang memiliki pemahaman yang baik dalam mengelompok pecahan berdasarkan jenisnya ini dikatakan telah mampu mengasimilasikan informasi yang sampai kepadanya. Karena materi pecahan ini telah dipelajari sebelumnya dan juga telah tersedia sejak di Sekolah Dasar. Informasi mengenai bentuk pecahan telah ada di pemikiran S1, sebelum S1 mengerjakan tes materi pecahan ini. Penggunaan pecahan dalam bentuk berbeda ini juga banyak sekali ditemukan dalam kehidupan sehari-hari. Informasi yang diterima S1 ketika melihat dan membaca soal ini kemudian dikelompokkan kedalam istilah yang sebelumnya telah diketahui. Proses kognitif yang terjadi ketika S1 mengintegrasikan persepsi, konsep atau pengalaman baru ke dalam skema yang ada dalam pikirannya ini disebut asimilasi (Subanji \& Supratman, 2015).

Dalam usahanya untuk mengurutkan pecahan dari yang terkecil ke yang terbesar, S1 telah memahami sebelumnya bahwa perlu untuk menyatakan setiap pecahan kedalam bentuk yang sama. Dalam hal ini diubah terlebih dahulu kedalam bentuk pecahan biasa. Artinya S1 memiliki informasi di otaknya bahwa keempat pecahan berbeda pada soal pertama ini perlu diubah kedalam bentuk pecahan biasa. Selanjutnya S1 menyamakan nilai penyebut dari pecahan-pecahan yang sebelumnya telah diklasifikasikan berdasarkan jenisnya. Pada tahapan ini terlihat jelas bahwa informasi tentang konsep pembilang dan penyebut juga telah difahami oleh S1. Pada tahapan ini S1 tidak menunjukkan indikasi melakukan miskonsepsi.

Setelah merubah semua pecahan ke dalam bentuk pecahan biasa, S1 tidak mampu mengidentifikasi pecahan mana yang memiliki nilai paling kecil atau paling besar. Ketika berhadapan dengan dua pecahan yang memiliki nilai pembilang yang sama yakni $\frac{7}{6}$ dan $\frac{7}{20}$, S1 tidak mampu menentukan mana yang lebih besar diantara keduanya. S1 menganggap $\frac{7}{20}$ lebih besar karena memiliki penyebut yang nilainya lebih besar dari $\frac{7}{6}$. S1 berusaha memahami informasi baru mengenai konsep pembilang dan penyebut. Menurut psikologi kognitif, timbulnya miskonsepsi pada tahapan ini disebabkan adanya akomodasi pada otak manusia dalam menanggapi dan memahami informasi baru yang diterimanya (Maulana, 2010).

Akibat dari informasi tentang konsep pembilang dan penyebut yang diterima S1 belum mampu diproses secara benar pada kerangka kerja akomodasi, S1 melakukan kesalahan dalam menyamakan 
penyebut dari pecahan-pecahan pada soal pertama. Saat proses penyamaan penyebut, S1 mengabaikan nilai dari pembilangnya. S1 juga tidak berusaha untuk menyamakan terlebih dahulu penyebut dari keempat pecahan tersebut.

Ketika S1 secara sistematis menggunakan aturan yang salah atau mengunakan aturan yang benar, tetapi digunakan di luar aplikasinya. Maka hal ini mengakibatkan miskonsepsi berikutnya kembali terjadi. Pada akhirnya S1 salah dalam mengurutkan keempat pecahan berbeda pada soal pertama.

Tabel 2. Miskonsepsi Klasifikasional yang Dilakukan Subjek

\begin{tabular}{|c|c|c|}
\hline $\begin{array}{c}\text { Indikator } \\
\text { Miskonsepsi } \\
\text { Klasifikasional }\end{array}$ & \multicolumn{2}{|r|}{ Perilaku Subjek yang Menunjukkan Miskonsepsi } \\
\hline $\begin{array}{lr}\text { Siswa melakukan } \\
\text { kesalahan dalam } \\
\text { mengurutkan } \\
\text { pecahan }\end{array}$ & Akomodasi & $\begin{array}{l}\text { 1. S1 salah dalam memahami konsep menyamakan } \\
\text { penyebut pecahan } \\
\text { - S1 tidak menggunakan konsep KPK dalam } \\
\text { menyamakan penyebut pecahan } \\
\text { 2. S1 salah dalam memahami konsep membandingkan } \\
\text { pecahan } \\
\text { - S1 tidak mengubah pecahan menjadi pecahan senilai } \\
\text { - S1 salah dalam memahami bagaimana konsep } \\
\text { menyamakan penyebut pecahan sebelum } \\
\text { membandingkan pecahan }\end{array}$ \\
\hline
\end{tabular}

\section{Miskonsepsi Teoritikal}

Miskonsepsi teoritikal merupakan bentuk miskonsepsi yang didasarkan atas kesalahan dalam mempelajari fakta-fakta atau kejadian-kejadian dalam sistem yang terorganisir. Indikator yang dapat dijadikan tolak ukur dalam menilai apakah S1 melakukan miskonsepsi teoritikal ini adalah; (1) Siswa menganggap operasi hitung pada pecahan sama dengan operasi hitung pada bilangan bulat; (2) Siswa tidak dapat dapat menentukan urutan yang tepat dari beberapa jenis operasi hitung pecahan (Amien, 1990).

\section{Miskonsepsi Teoritikal S1}

Ketika menjawab soal kedua poin a, S1 telah mampu menentukan operasi hitung mana yang seharusnya dikerjakan terlebih dahulu ketika berhadapan dengan lebih dari satu jenis operasi hitung. S1 menyebutkan bahwa operasi pembagian harus dikerjakan terlebih dahulu sebelum mengerjakan operasi penjumlahan. Proses S1 dalam menenetukan urutan yang tepat dalam melakukan operasi hitung pecahan ini didasarkan atas kenyataan bahwa S1 yang telah mampu mengasimilasikan informasi yang sampai kepadanya. Dimana, informasi ini kemudian dikelompokkan kedalam istilah yang sebelumnya telah diketahui. Hal ini sesuai dengan makna dari proses asimilasi itu sendiri yakni proses interpretasi dari suatu peristiwa dengan menggunakan istilah struktur kognitif yang ada. Piaget (Kaasila et al., 2010).

Meskipun S1 memilki pemahaman yang baik tentang urutan operasi hitung pecahan, S1 ternyata tidak dapat melakukan operasi hitung pecahan dengan benar. S1 mengingat bahwa ketika membagikan dua pecahan, operasi hitungnya diganti menjadi operasi perkalian dan salah satu bilangan pecahannya dibalik. Namun ketika menjumlah pecahan yang penyebutnya berbeda, S1 tidak dapat menyelesaikannya dengan benar meski melalui tahapan sepereti membaca kembali buku paket dan bertanya kepada peneliti. S1 
menjumlah semua bilangan penyebut dan semua bilangan pembilangnya. S1 menganggap operasi hitung pecahan sama dengan operasi hitung bilangan bulat. Dalam tahapan ini, terdapat ketidaksesuaian struktur masalah dengan struktur pemikiran yang dimiliki S1. Akibatnya S1 perlu meningkatkan pengetahuan dengan memodifikasi struktur untuk memperhitungkan pengalaman baru dengan cara kembali membaca buku dan bertanya dengan peneliti. Hal ini dikarenakan dalam proses akomodasi struktur pengetahuan yang ada tidak dapat secara langsung menyerap rangsangan baru karena perlu fase untuk memodifikasi struktur untuk mengatasi rangsangan baru dan kemudian akan diintegrasikan (Subanji \& Nusantara, 2016).

Selanjutnya pada soal kedua poin b. S1 telah mampu menetukan urutan yang tepat ketika harus berhadapan dengan lebih dari satu operasi hitung. S1 mengatakan bahwa operasi hitung yang harus dikerjakan terlebih dahulu adalah bilangan yang di dalam tanda kurung. Setelah menyelesaikan operasi yang berada dalam tanda kurung, S1 kemudian melakukan operasi hitung perkalian dan terakhir penjumlahan. Artinya S1 berhasil menginterpretasikan urutan operasi hitung pecahan ini dengan tepat menggunakan istilah struktur kognitif yang telah ada dalam pemikiran S1.

Tahapan selanjutnya, S1 mampu membagikan dua pecahan. Dimana, langkah yang dilakukan S1 adalah dengan mengganti operasi hitung pembagian menjadi operasi perkalian dan salah satu bilangan pecahannya dibalik. Namun ketika menjumlah pecahan yang penyebutnya berbeda, S1 tidak dapat menyelesaikannya dengan benar. S1 tidak memahami konsep menyamakan penyebut, akibatnya S1 menjumlah semua penyebut dan pembilangnya. S1 masih beranggapan bahwa operasi penjumlahan pecahan sama dengan operasi penjumlahan bilangan bulat. Disini S1 kembali mengalami kegagalan dalam menciptakan langkah baru atau memperbarui ataupun menggabung-gabungkan istilah lama dalam menghadapi tantangan baru. Artinya, S1 mengalami miskonsepsi dalam mengakomodasi konsep operasi hitung pecahan.

Tabel 3. Miskonsepsi Teoritikal yang dilakukan Subjek

\begin{tabular}{|l|l|l|}
\hline \multicolumn{1}{|c|}{$\begin{array}{c}\text { Indikator } \\
\text { Miskonsepsi } \\
\text { Teoritikal }\end{array}$} & \multicolumn{2}{|c|}{ Perilaku Subjek yang Menunjukkan Miskonsepsi } \\
\hline $\begin{array}{l}\text { Siswa melakukan } \\
\text { kesalahan dalam } \\
\text { mengurutkan } \\
\text { pecahan }\end{array}$ & Asimilasi & $\begin{array}{l}\text { S2 salah dalam memahami konsep urutan operasi hitung } \\
\text { pecahan }\end{array}$ \\
& Akomodasi & $\begin{array}{r}\text { S1 salah dalam memahami konsep penjumlahan pecahan } \\
\text { - S1 tidak memahami konsep pecahan senilai }\end{array}$ \\
& & - S1 tidak menyamakan penyebut pecahan \\
& & \\
& & S1 mengangap penjumlahan pecahan sama dengan \\
& & \\
\hline
\end{tabular}

\section{Miskonsepsi Korelasional S1}

Pada soal ketiga, S1 menuliskan apa yang diketahui dan ditanyakan dari soal. S1 berpikir cukup lama saat mencoba mencari tahu apa yang diketahuidan apa yang ditanyakan dari soal. Peneliti harus memberikan analogi yang lebih sederhana untuk mendorong S1 agar dapat memahami apa yang diketahui dan apa yang ditanyakan dari soal. Pada akhirnya S1 mampu mengungkapkan apa yang diketahui dan apa 
yang ditanyakan dari soal dengan mencoba memahaminya dari analogi permasalahan yang berbeda yang disampaikan peneliti.

S1 memerlukan waktu yang lama untuk mengulang membaca soal, berpikir dan bertanya pada peneliti. Meskipun membutuhkan waktu yang lama, S1 pada akhirnya mampu menuliskan apa yang diketahui dan ditanya dari soal. Pada tahapan ini dapat dilihat bahwa S1 telah berhasil menyesuaiakan struktur masalah dengan struktur pemikirannya, meskipun melaui proses seperti membaca buku dan bertanya kepada peneliti. S1 yang telah mampu mengetahui apa yang diketahui dan apa yang ditanyakan pada soal juga mampu menyelesaikan soal ketiga ini dengan baik. Dalam proses akomodasi ini, struktur pengetahuan yang ada tidak dapat secara langsung menyerap rangsangan baru karena perlu fase untuk memodifikasi struktur untuk mengatasi rangsangan baru dan kemudian akan diintegrasikan (Subanji \& Nusantara, 2016).

Dalam menyelesaikan permasalahan yang berkaitan dengan operasi hitung pecahan ini, S1 mengadakan penyesuaian (adaptasi) dengan lingkungannya melalui proses akomodasi. Keberhasilan S1 dalam meningkatkan pengetahuan dengan memodifikasi struktur untuk memperhitungkan pengalaman baru ini membuktikan bahwa S1 tidak melakukan miskonsepsi meskipun masih ada konsep yang belum difahami dengan baik.

\section{KESIMPULAN}

Berdasarkan hasil penelitian dapat ditarik kesimpulan bahwa siswa terjadi miskonsepsi siswa dalam menyelesaikan soal materi pecahan berdasarkan kerangka kerja asimilasi dan akomodasi. Hasil penelitian menunjukkan miskonsepsi yang dilakukakan siswa MTs N 4 kerinci dalam menyelesaikan soal pecahan berdasarkan kerangka kerja asimilasi dan akomodasi adalah sebagai berikut:

1. Miskonsepsi klasifikasional timbul akibat adanya proses akomodasi dalam otak siswa dalam menanggapi informasi baru mengenai konsep menyamakan penyebut dan membandingkan pecahan. Siswa tidak mengubah pecahan menjadi pecahan senilai. Siswa tidak mampu menggunakan konsep KPK dengan baik dalam menyamakan penyebut pecahan. Siswa juga salah dalam memahami konsep pecahan untuk menyatakan sebagian dari keseluruhan, dimana siswa tidak memahami makna dari pembilang dan penyebut. Dalam membandingkan pecahan, siswa tidak membandingkan seluruh pecahan secara bersamaan. Meskipun ada konsep yang difahami oleh siswa, dalam menjawab siswa masih menunjukkan miskonsepsi. Miskonsepsi atau kesalahfahaman siswa dalam memahami langkah-langkah dalam mengklasifikasikan pecahan berdasarkan urutannya dari yang terkecil hingga ke yang terbesar inilah yang mengindikasikan siswa melakukan miskonsepsi klasifikasional.

2. Miskonsepsi teoritikal yang dilakukan siswa dalam menyelesaikan soal yang berkaitan dengan operasi hitung pecahan timbul dari kesalahfahaman siswa dalam menginterpretasikan konsep urutan operasi hitung pecahan. Ketika dihadapkan dengan lebih dari satu operasi hitung, siswa belum mampu mengasimilasi informasi tentang urutan yang tepat dari beberapa operasi hitung pecahan untuk kemudian dikelompokkan kedalam istilah yang mereka telah ketahui sebelumnya, dalam hal ini operasi hitung bilangan bulat. Melakukan operasi hitung penjumlahan pecahan. Miskonsepsi 
klasifikasional yang dilakukan siswa juga berasal dari ketidaksesuaian struktur masalah dan struktur pemikiran siswa (akomodasi). Siswa salah dalam memahami konsep penjumlahan pecahan. Dalam menjumlahkan pecahan, siswa tidak memahami bagaiamana mengubah pecahan menjadi pecahan senilai. Siswa tidak menyamakan penyebut pecahan karena tidak mampu menggunakan konsep KPK dengan baik ketika menyamakan penyebut pecahan. Siswa menganggap operasi penjumlahan pada pecahan sama dengan operasi penjumlahan pada bilangan bulat. Kesalahan siswa dalam memahami kejadian-kejadian khusus yang saling berhubungan ini mengakibatkan siswa mengalami miskonsepsi teoritikal. Kesalahan yang dilakukan siswa juga berkaitan dengan keslahan observasi-observasi yang terdiri atas dugaan-dugaan terutama dalam formulasi prinsip-prinsip umum operasi hitung pecahan dan operasi hitung bilangan bulat.

3. Siswa tidak menunjukan indikasi mengalami miskonsepsi korelasional karena kriteria jawaban siswa dalam menjawab soal tentang permasalahan yang berkaitan dengan operasi hitung pecahan tidak menunjukkan miskonsepsi meski hanya sebagian konsep yang difahami oleh siswa. Dalam situasi berbeda, siswa yang salah dalam menjawab soal tentang permasalahan yang berkaitan dengan operasi hitung pecahan juga tidak menunjukkan indikasi miskonsepsi korelasional karena jawaban yang diberikan siswa masuk dalam kriteria tidak memahami konsep.

\section{REFERENSI}

Akdeniz, A. R., Bektaş, U., \& Yiğit, N. (2000). The 8th grade students' levels of understanding of the introductory physics concepts. Hacettepe University Journal of Education, 19, 5-14.

Alghazo, Y. M., \& Alghazo, R. (2017). Exploring Common Misconceptions and Errors about Fractions among College Students in Saudi Arabia. International Education Studies, 10(4), 133-140.

Amien, M. (1990). Pemetaan Konsep Suatu Teknik untuk Meningkatkan Belajar yang Bermakna. Mimbar Pendidikan, 2(9), 55-69.

Ausubel, D. P., Novak, J. D., \& Hanesian, H. (1968). Educational psychology: A cognitive view.

Creswell, J. W. (2002). Educational research: Planning, conducting, and evaluating quantitative. Prentice Hall Upper Saddle River, NJ.

Fidan, N. (1986). Okulda öğrenme ve öğretme.

Kaasila, R., Pehkonen, E., \& Hellinen, A. (2010). Finnish pre-service teachers' and upper secondary students' understanding of division and reasoning strategies used. Educational Studies in Mathematics, 73(3), 247-261.

Kemendikbud. (2012). Kemampuan Matematika Siswa SMP Indonesia.

Maulana, P. (2010). Usaha mengurangi terjadinya miskonsepsi fisika melalui pembelajaran dengan pendekatan konflik kognitif. Jurnal Pendidikan Fisika Indonesia, 6(2).

Meşeci, B., Tekin, S., \& Karamustafaoğlu, S. (2013). Maddenin tanecikli yapisiyla ilgili kavram yanilgilarinin tespiti. Dicle Üniversitesi Sosyal Bilimler Enstitüsü Dergisi, 9, 20-40. 
Moleong, L. J. (2013). Metodologi Penelitian Kualitatif (ketigapulu). Bandung: PT Remaja Rosdakarya.

Subanji \& Nusantara, T. (2016). Thinking Process of Pseudo Construction in Mathematics Concepts. International Education Studies, 9(2), 17-31.

Subanji, R., \& Supratman, A. M. (2015). The pseudo-covariational reasoning thought processes in constructing graph function of reversible event dynamics based on assimilation and accommodation frameworks. Research in Mathematical Education, 19(1), 61-79.

Suparno, P. (2013). Miskonsepsi \& perubahan konsep dalam pendidikan fisika. Gramedia Widiasarana.

Thompson, F., \& Logue, S. (2006). An exploration of common student misconceptions in science. International Education Journal, 7(4), 553-559. 